UDC 33:17:629.78

LBC 65.375

\title{
TECHNOLOGICAL DETERMINISM GOES ALOFT: NOTES ON THE HUMAN - MACHINE ISSUE IN OUTER SPACE EXPLORATION
}

\author{
Lika Rodin \\ University of Skövde, Skövde, Sweden
}

\begin{abstract}
The future of space exploration is unimaginable without broadening the role of technology. Already, the necessity of manned space expeditions is becoming increasingly problematized. This study looks at the role of technology and human - machine relationships unfolding within national space programs through the lens of the 'soft' version of technological determinism suggested by Albert Borgmann. This theoretical tradition recognizes, without neglecting human agency, the shaping effect of technology on human organization, prosperity and actions as well as on individuals' relationships with the self and other. The commodification of technology - economic and ethical - is viewed to be the effects of technological expansion. Ethical commodification is characterized by disattachment of the individual from the natural surrounding and from the self. In the field of space exploration, ethical commodification is associated with the process of automation that developed differently in distinctive national contexts. Thus, if the history of American spaceflight is characterized by the initial struggle against automation, seen to be a means of disempowering astronauts as a professional group, the Russian space program favoured automation from the very beginning. In both contexts, however, automation eventually established itself and continues to shape contemporary perceptions on spaceflight. The accumulated experiences of man-machine interactions are useful for understanding ethical commodification as a social phenomenon. Drawing on the autobiographical narratives of Soviet / Russian cosmonauts, I specify the ways in which ethical commodification of hardware and software manifested itself in spaceflight and how it could be diverted. In conclusion, a perspective that resists alienation is suggested for the enterprise of space exploration at large.

Key words: space exploration, automatization, commodification, human - machine interactions, ethical commodification.
\end{abstract}

УДК $33: 17: 629.78$

ББК 65.375

\section{ТЕХНОЛОГИЧЕСКИЙ ДЕТЕРМИНИЗМ УХОДИТ ВВЫСЬ: ЗАМЕТКИ О ПРОБЛЕМЕ ЧЕЛОВЕК - МАШИНА В ОСВОЕНИИ КОСМОСА}

\author{
Лика Родин \\ Университет Сковде, г. Сковде, Швеция
}

\begin{abstract}
Аннотация. Будущее освоения космического пространства немыслимо без расширения роли технологий. Уже сегодня необходимость в пилотируемых космических экспедициях становится все более проблемным вопросом. В данном исследовании рассматривается роль техники и отношений человека с машиной, разворачивающиеся в рамках национальных космических программ, через призму «мягкой» версии технологического детерминизма, предложенной Альбертом Боргманном. Не отрицая способности человеческой агентности, эта теоретическая традиция признает формирующее влияние технологий на общество, его процветание, человеческие действия, а также на отношения индивидов с собой и другими. Коммодификация технологий - экономическая и этическая - рассматривается как следствие технологической экспансии. Этическая коммодификация характеризуется отчуждением индивидов от естественного окружения и от самих себя. В области освоения космоса этическая коммодификация связана с процессом автоматизации, который развивался по-разному в различных национальных контекстах. Так, если история американской космонавтики характеризуется первоначальной борьбой с автоматизацией, которая воспринималась средством ослабления космонавтов как профессиональной группы, российская космическая программа с самого начала (a) поддерживала автоматизацию. Тем не менее в обоих случаях последняя в конечном итоге утвердилась и
\end{abstract}


продолжает формировать современные представления о космических полетах. Накопленный опыт взаимодействия человек - машина полезен для понимания этической коммодификации как социального явления. Анализ автобиографических рассказов советских / российских космонавтов, проведеннный в рамках данного исследования, демонстрирует, как этическая коммодификация аппаратного и программного обеспечения проявлялась в космических полетах и была нейтрализована. В заключении статьи предлагается перспектива противодействия отчуждению в деле освоения космоса в целом.

Ключевые слова: освоение космоса, автоматизация, коммодификация, взаимодействие человек - машина, этическая коммодификация.

\section{Introduction}

The future of manned spaceflight is a vibrant topic in contemporary public debates and academic discussions [Launius 2006; McCurdy 2006]. Questions about the rationale for the expansive, demanding and potentially dangerous enterprise of sending humans into outer space are raised by various stakeholders in different political contexts. And indeed, why not allow robots and computers to perform jobs aloft while humans reap the benefit of the data or other outcomes produced, sitting comfortably in their offices back on Earth? [Mindell 2008]. Such a development would broaden the role of technology in human society and transform the current understanding of human agency, control and well-being.

The issue of technology in space exploration was addressed by several disciplines and at different analytical levels. At the macro-level of analysis, space technology was studied in the context of national political ethos [Gerovitch 2011; 2014; 2015; Mindell 2006; 2008; Siddiqi 2010], international relationships [Krige 2006; Sariak 2017; Shayler 2017], warfare [Klein 2012], advocacy [Sadeh 2005], and cultural representations [McCurdy 2006]. At the mezzo-level, organizational features and interinstitutional interactions were taken into account [Brown 2006; Gerovitch 2006; 2014; Mindell 2006; 2008; Vaughan 2006]. At the microlevel, human - machine relationships, professional identities and practices were subjected to examination [Gerovitch 2006; 2014; Hersch 2009; Mindell 2006; 2008]. Finally, space-related technologies were considered within the domains of ontology [Clynes, Kline 1995; Clynes 1995] and epistemology [Arnould 2013]. This accumulated knowledge allows a broad view on the place of technology in the exploration and utilization of outer space, though the fundamental question of the perspectives of human direct presence in space still remains open.
This study aims to deepen the understanding of human - machine relationships in spaceflight and the role of technology in the enterprise of space exploration more generally. Previous research associated primarily with the disciplinary field of history indicated that certain political and professional groups might deliberately promote or suppress automation in the field of space exploration [Gerovitch 2006; 2015; Mindell 2006; 2008]. Framed in line with a liberal anthropocentric paradigm, these projects rather scarcely accounted for the dynamic force of technological development itself. In the current study, I rely on a 'soft' version of technological determinism that recognizes the shaping effect of technology on human organization, prosperity, actions and relationships with the self and other, simultaneously living open possibilities for reflexive practices capable of maintaining (even if partially) one's embodied and mindful existence within a technologized environment [Borgmann 2010].

The paper consists of four parts. First, I will reinterpret previous research on human - machine relationships, with a focus on the logic of technological progress. After that, Albert Borgmann's theory of commodification of technology will be presented and applied in the analysis of autobiographical reports from the Soviet / Russian space program. Finally, the (de)commodification framework will be employed to account for the perspective in the enterprise of space exploration at large. I conclude with anticipatory reflections around the role of technology in the future of manned spaceflight and its effects.

\section{The path to automation in spaceflight}

One of the central themes in the discussion on technology in outer space exploration is the 'automation versus human control' problem [Mindell 2008]. Automation is typically associated with pilots' deskilling and decrease in professional status, and 
therefore might be met with opposition [Mindell 2006; 2008; Gerovitch 2006]. In this section, I reread the research on American and Russian space programs to highlight the objective dynamics behind the move towards in-flight technologization in its explicit and implicit forms. Such focus does not deny the role of social-political processes, recognizing the mutual transformative interactions between different developmental forces. However, as follows from the previous research, automation tends to eventually establish itself and shape mainstream perceptions on spaceflight.

The American context. In the American context, the discussion on automation can be traced back to the early days of aviation and reflects the dynamics of exchange between two professional fields: aviation and astronautics. According to David Mindell [Mindell 2008, 20], the man-machine problem emerged in the early days of aviation from the stability-control issue. While stability - the capability of an airplane to regain a straight movement after a deviating manoeuver - was always seen as a desirable characteristic typically built into the very design of the aircraft, its excess meant a reduction of controllability in the form of human input. Historically, European engineers tended to prioritize stability features, whereas American aviation demonstrated a loyalty to pilots' controlling functions. Piloting as a profession enjoyed an elite status in the United States, having been strongly associated with exceptional tacit knowledge and practical skills. However, with the development of the air transportation industry, the situation changed. Long-duration and frequent flights put additional demands on pilots' physical and psychological strength, facilitating wider acceptance of automation in the cockpit. To compensate for their shrinking role in function control, aviators gained pluralization in the character of their missions, which from that point started to involve commercial and military interests. Moreover, pilots increasingly engaged in engineering training, which allowed them to participate in the development of cockpit instruments (e.g. artificial horizon and directional gyros) aimed at blind flying [Mindell 2008].

The automation trend culminated in the introduction of the autopilot capability [Mindell 2008]. In the 1950s - the age of jets the issue of stability had become associated more with the power of electronic devices steering the flight than with the airplane design. Pilots increasingly became elements of a complex managerial system built on the principle of a 'feedback loop', a cybernetic system. As presented in one of the public discussions, rather suddenly, the profession of aviation - that vocation of leather jackets and exciting experiences - has become a career of computer monitoring and equipment management. You ones thought you would dance on silver wings, and now you are merely tapping on a keyboard [Mindell 2008, 267].

The American spaceflight industry inherited from aviation the discussion on automation and human control. It turned out to be additionally coloured by the political objectives of the space exploration enterprise. Sending humans into outer space was especially important for national prestige and professional identity. As stated during public debates over the lunar Apollo program, 'it is a man, not merely machines, in space that captures the imagination of the world' [Mindell 2006, 148]. In an ideological sense, the image of manned spaceflight resonated with the traditional American values of individualism, self-directedness and selfefficiency. Still, astronauts had to struggle for a meaningful role in spaceflight performance. In the Apollo program, space flyers drew special attention to the moment of landing, perceived to be the crucial point of a lunar expedition. As a result, ideas of human agency, self-esteem and the explorative character of spaceflight were claimed to be incorporated into the design of the Apollo spacecraft itself [Mindell 2006].

Less enthusiastic commentators problematized the very notion of manual control in the context of high technologization. Joe Shea, a deputy director of Manned Space Flight (Systems) for NASA, indicated already in 1963 that the opposition between manual and automatic piloting is rather an 'emotional' feature of astronautics, since humans in the situation of manual landing control computers that actually steer the vehicle. In this sense, talking about the 'humanization' of the Apollo approach would be 'stretching things a bit', according to Shea [Mindell 2008, 263]. Moreover, human operations aloft were typically secured by intensive premission simulation training aimed at mastering the effective bodily and cognitive motions [Mindell 2006; 2008], and assisted by manuals and 
checklists, "a kind of "program" that ran on people instead of machines' [Hersch 2009, 7; Mindell 2008]. Instructions were employed in both within- and extra-vehicle activities. As an example, Neil Armstrong had a checklist integrated into his spacesuit while operating on the lunar surface [Hersch 2009].

In the 1970s, the space pilots' success was furthered in the framework of the Shuttle program, which, as some astronauts believed, was capable of restoring the dignity of the piloting profession [Mindell 2008]. Even in an aesthetic sense, the shuttle had an advantage over a more traditional space capsule. As one astronaut explained in regard to difference in landing, 'Whereas the Apollo command module fell into the sea, the crew recovered by helicopter like a bag of cats saved from a water grave', the space orbiter 'makes a smooth landing at the destination airport and the flight crew steps down from the spacecraft in front of a waiting throng in a dignified and properly heroic manner' [Mindell 2008, 264]. While human input was overly advocated, only one shuttle flight - STS2 - was allowed to realize this ideal. Typically, reentry was automatic, and only touchdown was performed manually. After the Columbia tragedy, even this routine was seriously reconsidered toward further automation [Mindell 2008].

The American discourse (both public and professional) around space exploration had been characterized by anthropocentrism grounded in the idea of human privilege and the related value of human agency as a prerequisite of individual and collective well-being. It was built on the aspiration of exploration as an expansion of 'the realm of human experience' unrelated to any special technological ambitions [Mindell 2008, 270]. In spite of this anthropocentric ideology, as above presented, a non-linear - but steady - move towards in-flight automation (technological and procedural) accrued, demonstrating the shaping role of technological progress. This development partly resonated with the realities and concerns of the Soviet / Russian space program.

The Russian context. According to some commentators, discussions around spacecraft automation within the Soviet space program of the 1960s and 1970s mirrored the fragmentation of the national space exploration community, in which engineering agencies, the military and scientific organizations occasionally pushed for distinctive objectives [Gerovitch 2006]. This mezzo-level dynamic might be complemented in some periods - similar to the American space enterprise presented above - by large-scale, social-political goals, including presage and geopolitical competition, which constructed an iconic image of a spaceman [Gerovitch 2006; 2011; 2014; 2015]. However, the publically promoted anthropocentric view on space exploration was almost separated from the technology-favouring agenda of engineering bureaus [Gerovitch 2006].

The first generation of Soviet manned spacecraft - Vostok - was highly automated, a fact mainly perceived by engineers and space program managers to be an advantage in the context of profound uncertainty associated with early space flights [Gerovitch 2006]. The positive initial experience laid the foundation for the further promotion of automation as a reliable, cost-efficient and safe solution. Spaceships were designed at first hand to function in an automatic regime, with additions made for manual operation. As a result, the cabin configuration of the next-in-line manned spacecraft Voskhod was not particularly suitable for performing the manual tasks that cosmonauts received from time to time. For instance, the illuminator and the control stick were situated very unsuitable and demanded from cosmonauts additional motions during the flight [Gerovitch 2006].

The next generation of space vehicles Soyuz - was thought to carry out a variety of new functions, including randomizing and docking [Gerovitch 2006]. It provided test pilots with the opportunity to raise their voices in favour of the human role in spaceflight. Some cosmonauts argued that in designing a spaceship, priority should be given to human activities and that automata can be left as a backup option. Distinct from their American counterparts struggling to reclaim landing procedures from machines, cosmonauts pressed on the issue of docking, an operation crucial in the long-duration and multivehicle missions characteristic of the Soviet space program. From that point, a cybernetic approach started coming more actively into play, though adaptation of system thinking might take some time. Crews were still frequently considered to be a supplementary rather than a fully integrated operational element [Gerovitch 2006]. Similar to 
astronauts [Hersch 2009; Mindell 2008], cosmonauts intensively practiced in-flight procedures on simulators, anticipating a variety of possible situations to achieve an almost automatic performance. In a broad sense, humans might, therefore, come to resemble machines [Gerovitch 2015].

With the development of long-duration space missions that increasingly demanded the maintenance and repair of technological devices, technical specialists came to be included as part of the crews. In contrast to test pilots, engineers might feel more comfortable with high automation and start to look for new objectives of spaceflight beyond basic survival and space manoeuvring. Valentin Lebedev, a Saluyt 7 flying engineer who spent 211 days in space in 1982, was instrumental in raising the question of the role of humans in outer space endeavours. The cosmonaut estimated that space flyers devoted only onefourteenth of the total time in mission to productive activity such as scientific research, while the rest was spent on maintaining their own existence [Gerovitch 2006, 135]. His related proposal was to rethink and enlarge the scientific (meaningful) content of spaceflight [Roscosmos TV... web]. One proposed solution to the problem of space mission efficiency was automation. As argued by another cosmonaut, Konstantin Feoktistov, 'No craft is designed to carry dead weight. It must have a payload that performs a kind of useful work... Every operation that can be automated on board a spaceship should be automated' [Gerovitch 2006, 136].

Undoubtedly, a distribution of influence between different occupational branches (i.e. military, civil aviation, engineering bureaus, scientific institutions) played a significant role in the development of the Soviet / Russian space program [Gerovitch 2006; 2015]; however, it can be argued that technological progress allowed the integration of engineers into the flying community as well as their anticipation and request for further automation. Moreover, activities of space flyers increasingly resembled machine-like logic, problematizing the very division of humans and machines. The section that follows provides a theoretical framework for further analysis of human - machine relationships in spaceflight. I introduce the notion of ethical commodification suggested by Albert Borgmann.

\section{(De)commodification of technology}

Borgmann [Borgmann 2010, 27] defined technology as tools and the 'procedures' associated with their utilization. The philosopher emphasized the particularity of modern technologies that emerged with the development of the market economy and wide industrialization of Western countries as refashioning humans' relationships with reality, raising new questions about the moral and ontological order. The main concern of the analytical discussion is the process of commodification that can be understood in economic and ethical terms. In an economic sense, commodity refers to a good that naturally exists or can be manufactured, but which is unavoidably brought to 'a market' for sale [Borgmann 2010, 28]. Commodification is a historical process that impacts the human condition in a variety of ways. It gradually established itself in industrial countries alongside the initially non-economic sphere of intimate relationships and public goods. A strong, but actively debated intellectual tradition exists that links economic commodification with impoverishment.

Ethical commodification plays out along with or separately from economic commodification. When '[a] thing or a practice is morally commodified...it is detached from contexts of engagement with a time, a place, and a community' [Borgmann 2010, 29]. This 'detachment' from the significant aspects of social reality is typically viewed to be impoverishing, though it might be justified by prospective benefits manifesting themselves in the form of freedoms, justice or well-being. In the case of technology, economic and moral commodifications do not always accompany one another. Thus, while agriculture is an economic domain, it is unimaginable without reference to the specific places and people involved in farming as well as to a specific biological rhythm. From another perspective, internet content can be promoted as non-economic goods while being decoupled from situated bonds and responsibilities. An easy access to and withdrawal from communication sites problematizes the very nature of community that they attempt to construct. In this sense, '[e]lectronic devices and goods have always already been detached' [Borgmann 2010, 30].

Commodification differentiates 'the nature of reality' from 'norms of conduct':

In the eighteenth century England, bread was not an object that required the mechanism of the market to establish its value, norms of social justice to judge 
its distribution, standards of nutrition to fix its composition, and rules of dieting to direct its consumption. The sight of bread provoked gratitude. If it was entirely made of wheat, it was evidence of wealth. Sitting down to break it was an occasion of rest and grace. Bread was the focal point of a context of work and of working together - during harvest time when all able-bodied people had to help, in the barn when the threshers did their rhythmic flailing, at the mill when wheat was entrusted to the miller, at the village oven where all families took their loaves to have them baked [Borgmann 2010, 30].

In 'pre-technological times', the reality of social life was stable and intelligible. People's relationships with their material surroundings found direct expression in emotional and bodily experiences. However, with industrialization and marketization, objects and activities lost their situated character, turning instead into products of rationalized and technologized processes. Reality became separated from moral obligations and concerns; commodified goods turned mystical by the idea of machinery, as ever-present, immediate, unproblematic and effortlessly accessible. In this respect, '[m]oral commodification is always about mechanization' [Borgmann 2010, 31]. The commodification of bread is associated with the mechanization of its production that became a part of a larger process of industrialization. The contemporary tendency is to foster the mystical aspect by making machinery as less evident as possible and the commodity as appealing as possible. A personal computer is a telling example. With its size dramatically reduced, the major concern nowadays is to keep computers ergonomically adequate for human use [Borgmann 2010].

Technological development goes hand in hand with a desire for comfort and, in turn, facilitates ethical commodification of technology. Presently, cars and computers are reaching a level of sophistication that precludes the possibility of a lay-user intervention in the form of repair or improvement. Here, a 'device paradigm' comes into play: humans might accept the mystery of machinery to satisfy the desire for comfort, representing a form of 'moral consumption' [Borgmann 2010, 33]. With regard to personal computers, the following is argued:

Typically also, the exponential increase in the power of computers was directed, not to challenge human discipline and skills in newly created ways but to make the commodities of information and entertainment more instantly, ubiquitously, safely and easily available. Computers, to be sure, are skillfully [sic] used by highly trained experts... But such expert use is rarely just an exercise in the pursuit of excellence. It usually serves to improve the machinery of technology or to produce commodities of entertainment [Borgmann 2010, 32].

Highly technologized societies can be relatively coherent but simultaneously artificial, since the foundation of existence is substituted by morals. Following this logic, a trip in a highly automated car can no longer be clearly differentiated from an evening spent in one's living room: air conditioning, broadcasting devices and other attributes of comfort are available in the modern car. Experiences of a car trip, then, lack the particularity of the context as well as specific references to the environmental and interpersonal condition. In this way, high-tech society cultivates 'disengagement' that is justified by striving towards escape from the difficulties and discomforts of daily life. But technologically ensured freedom might eventually turn into a devastation of human relationships and degradation of individual agency and capabilities. The reversal of ethical commodification, according to Borgmann [Borgmann 1984; 2010], may involve the 'destandardization of goods' and the restoration of 'life-worlds' that would promote one's connections with time, place and community.

\section{Experiences of the Soviet / Russian space program}

Technologization is unavoidably accompanied by commodification [Borgmann 2010]. In this part of the paper, I draw on the narratives accumulated in the framework of long-duration Soviet / Russian space missions to account for some of the possible strategies for overcoming alienation. Although Borgmann's theory was built on observations over market-driven social systems, technology (and not the economy) is viewed to be the main shaping factor in social development. As ethical commodification is not necessarily bound to the realm of economic exchange, this concept can therefore be applied to the analysis of non-market societies as well.

The following presentation does not aim to exhaust the whole range of approaches to the decommodification of technology in spaceflight. 
Rather, it demonstrates that variation in human machine interactional practices might reflect the plurality of entities accommodated under the label of technology. While some scholars associate space technology primarily with advanced (typically digital) devices [Gerovitch 2006; 2014; Mindell 2008], others include into the technological family procedures and supporting materials [e.g. Borgmann 2010; Hersch 2009]. In this study, I additionally differentiate between hardware (technological constructions) and software (analogue or digital programs), claiming that ethical decommodification of software might be a more challenging task due to its disembodied character.

As is known, the Soviet / Russian space program turned to long-duration space missions in the early 1970s after the exhaustion of mainly unrealized lunar projects [Gerovitch 2014]. Anumber of space stations were put on low orbit, including several Salyut space stations (1971-1991) and the orbital complex Mir (1996-2001). A large-size construction, the space station was equipped with a smart life support system, allowing the accommodation of cosmonauts for weeks and months. The long-term stay motivated the space flyers to develop certain relationships with the technological construction. Some could define the station as a 'home', others went even further to humanize it. Yuri Usachjov, an engineer who served two missions (in total, 275 days) at the orbital complex Mir in the mid-1990s, reported in his autobiography on cosmonauts' reflections over their established bonds with the space station [Usachjov 2004]:

Then the conversation went on about the station and an interesting thought sounded: she (the station) has a very specific lifetime, unfortunately, much shorter than even half of human life i.e., less than $30-40$ years. We are eager to meet her, we will live with her a little and leave... And we are eager to return here again, we do not know. It is similar at the same time to the fate of domestic animals, whose age is shorter than the human, and to parting with old parents - when you say goodbye, leaving for a long time, you do not know for sure whether you will find them alive or not on your next visit.

The word station (stancija) has a female gender in the Russian language, and this linguistic feature facilitates the 'humanization' of the technological construction. In the extract presented, the station no longer appears as an anonymous shell temporarily sheltering the space flyers, but as a family member whose lifespan is compared with that of humans. Moreover, the station is shirked to the size of a 'pat' that provokes emotional attachment and soft paternalism. It is the one who is unmovable and dependent, while humans exercise agency (to stay or / and leave) and control. It is always there, in a known location, waiting to be found and attended to. In this way, shared time, space and community had been (re)constructed.

The materiality of hardware eases ethical decommodification. Comparison of the station with the aged body of a parent triggers an emotional response and eventually restores engagement. Another example of this move comes from the cosmonaut's reflection over landing in a Soyuz descent capsule [Usachjov 2004]:

And as the culmination, the shooting of the lid of the parachute container and the release of a parachute. Lord, how 'iron' - our descent vehicle stands such treatment. We are beginning to be 'tormented' by the atmosphere with strong lateral overloads. This is some kind of complex movement, but it feels like someone very big holds our descent vehicle for strings of a parachute line and tries to restrain our fall into the atmosphere.

In this episode, a parallel is drawn between the iron body of the space capsule and human flesh that can feel pain and suffer. The power balance is reversed this time, with recognition of the 'caring' role of technology. Thus, a rigid and technical division of labour and roles, typical for industrial society, is destabilized. Care is placed in the centre of human - machine relationships.

Upon his return to Mir, Usachjov finds it aged like an 'old lady', as ten years is a long period of time in space. The cosmonauts wonder how the station survives the pressure and temperature fluctuations [Usachjov 2004]. This attitude of humanization might be found in the early long-term missions as well. Cosmonaut Vladimir Savinyh participated in a repairer mission to Salyut 7 in 1988 after the orbital complex, flying in automatic regime, stopped responding to ground control, titled his autobiographical book devoted to this life episode Notes from the Dead Station (1999). In the book, the whole mission is framed in terms of reanimation of the 'living body' of the station, returning function to its different systems as living organs [Savinyh 1999]. Technological devices are not just humanized but, at times, personalized in the cosmonauts' autobiographical materials. Usachjov [Usachjov 
2004] reported on a discussion that took place during his first mission around Progress resupply vehicles. One of the cosmonauts suggested replacing formal numerical identification by names of characters from popular movies and fairy tales.

A space station is a huge piece of hardware to which cosmonauts, by virtue of the situation, had to develop a certain attitude. As demonstrated above, the orbital complex might become included in the web of symbolic bonds by acknowledging shared materiality and temporality of existence. In this way, the cosmonauts reconstructed intimacy with the technological environment. Borgmann [Borgmann 1984, 207] used the notion of 'practices of engagement' that enable recontextualization of objects and events.

Decommodification of software is a more complex process. Cosmonaut Valentin Lebedev, who was among the first space flyers adapting to the Soyuz $T$ launch vehicle, described the initial frustration over on-board digital computers in his 1988 book, Diary of a Cosmonaut: 211 Days in Space. His first impression was of a passenger-like role that contrasted with flyers' previous relatively restricted - but still notable - involvement in navigation procedures. All calculations, adjustments and manipulations aboard Soyuz $T$ were performed by software, and the cosmonaut needed only to start the program and supervise it. As with previous version of Soyuz, space flyers were expected to interpret data, make judgments or anticipations over a situation and decide on possible actions. Some manoeuvers were especially demanding; for example, docking could generate fifty-three potential problems. Cosmonauts trained on those procedures for months in order to successfully master techniques, a condition that fostered cosmonauts' self-esteem, dignity, self-confidence and particular relationships with the technological devices. As reported by Lebedev [Lebedev 1988, 205], 'In it (in old Soyuz) I felt an intelligent man and in control'. Human and machine were co-situated in space-time and linked by the chain of interactions. Digitalization led to the 'black boxing' of devices: what was happening inside the computer became mainly unknown and unintelligible, at least in the beginning [Lebedev, 1988, 205-206]:

On the new spaceship somebody, a mysterious 'ankle', does everything for you. You just sit and watch. If something goes wrong, you don't need to worry, because there is no danger. 'I, Master Computer, will take care of it. I have all the control programs I need, but if necessary, I'll turn everything off for you, or switch to sensor or engine reserve. I'll tell you what went wrong and how I corrected it. And you, 'my intelligent passenger', can look at the data and give reports to the Ground'.

In this extract, the 'mystery' of digital technology [Borgmann 2010] manifests itself by concealing operational procedures. While this regime assists disburdenment of the cosmonaut, it simultaneously separates him from the environment and pushes him into a passive role. In this way, commodification of technology manifests itself. Gradually, however, the space flyer mastered new skills - 'like a blind man regaining his sight' [Lebedev 1988, 206] - that allowed him to be included in the feedback loop. The cosmonaut learned to anticipate and correct possible errors in the program itself:

Because of my experience I am now ahead of the computer and can foresee what it will do. It isn't a mystery to me anymore. Before, I couldn't think as fast as it did to know what was going on inside it. Suddenly, it would display some kind of error code, which I would try to figure out. While I was thinking, the machine would already clear the problem. Now I work quietly, with self-confidence; I see a display of parameters, evaluate them, and make estimation about the process going on. Now I even get some time to look at the machine from the outside. Does it really do the necessary operations in the best way? I look at it: Let's see now... this is going on; if this parameter is such and such, then that will happen. If this is a problem, I can reenter data into the computer. As a result I am beautifully able to remain constantly up to date and prepared for any maneuver [sic], such as engine firing or orientation keeping, without the hectic complication of continuous preparation [Lebedev 1988, 206].

Restoring shared time and space via conscious awareness and mastered calculative approximations, the spaceman eventually reestablished human positioning in regard to digital devices as a flexible and holistic thinker. Borgmann [Borgmann 1984, 41-42] emphasized the importance of skills that facilitate human 'engagement' with the world and strengthen identities. Skills are requested in one's relationships with 'things', while interactions with 'devices' are typically non-demanding. A traditional stove that provided heating for the house had to be attended to by the whole family: firewood had to be prepared 
and arranged, and the fire had to be maintained. In this collaborative labour and familiarity with each other's functions, a social context was created. In contrast, devices are elements of the world of consumption. They foster a regime of facelessness (of both producers and consumers), division and decontextualization. The attempts of the Russian cosmonauts to regain meaningful control over digital technology should then be seen as an opposition to ethical commodification.

Similar practices of re-engagement can be found in the framework of the American space program as well. Thus, checklists utilized in space missions might be complemented by humoristic notes and drawings expressing support or greetings, functioning as a medium between the ground-based personnel and flying crews. From a different perspective, the astronauts themselves might alter instructions with cartoons, signatures and, at times, unauthorized materials to facilitate group dynamics during the flight [Hersch 2009]. In this way, checklists turn from unspecified 'devices' into 'definite things' [Borgmann 1984].

\section{Discussion and conclusion}

This study was devoted to the discussion of human - machine relationships as they played out in the context of the Soviet / Russian space program of the 1980s and 1990s. Distinct from the mainstream liberal-constructivism approach that focuses on the transformative agency of the individual and collective human actors pushing for particular value-driven goals that can or cannot account for the ideals of selfdirectedness and self-determination, I emphasized the shaping role of technology in space enterprise and in social development in general.

Borgmann's philosophical conception employed in the current study allows for a nonreductionist interpretation of contemporary social processes at different levels of sociality, with an emphasis on the ecological aspects of human existence (i.e. engagement with surroundings) and therefore is particularly helpful. According to 'soft' determinism, technologization is relatively objective and self-propagating; technology increasingly becomes our ontology, defining and satisfying human needs [Borgmann 1984]. Having been interwoven with a desire for comfort - a form of 'moral consumption' [Borgmann 2010, 33] - technological development leads to the alienation of humans from technical tools, each other and the environment. An alternative to the device paradigm is 'focal life', which is aimed at restoring social 'engagement' [Borgmann 2010, 34]. This move will require the re-embodiment and recontextualization of objects and practices as well as the restoration of their complexity and internal coherence. 'Focused' things and events are not necessarily regions of pretechnological existence. Humans have to learn how to overcome (at least partially) ethical commodification without rejecting the benefits of technological progress. This, in turn, will transform human society as a whole: 'It will produce fewer cars and more buses and trains; fewer jet skis, more canoes; fewer DVD's, more books; fewer iPads and more flutes and guitars' [Borgmann 2010, 34]. The reform of the device paradigm will, therefore, be in its restriction to the supplement position to give 'focal life' a priority [Borgmann 2010].

In the field of space exploration, de-alienation can be achieved not only (or not necessarily) by making digital devices more user-friendly (for a related discussion, see Gerovitch: [Gerovitch 2015]). According to Borgmann [Borgmann 1984, 47], 'friendliness' is just the mark of how wide the gap has become between the function accessible to everyone and the machinery known by nearly no one'. The alternative way, as demonstrated in the analyses, is a restoration of one's meaningful connectivity with social and physical reality.

The accumulated knowledge proposes a direction for anticipatory reflections around the role and place of technology in human history, including the future of manned spaceflight. Why send humans into outer space if the majority of outer space assignments can soon be carried out by technological agents? Humans might stay safe, without additional costs, at their terrestrial locations; here, they would monitor aloft robotic operations on the basis of visual and other types of data. With this scenario realized, we will know the cosmos mainly from pictures and mathematical representations, turning it eventually into something anonymous and superficial. We will perceive outer space and solar bodies though smart plans of their utilization, calculating and competing for the highest profit. In this context, the chances of our detachment from the extraterrestrial environment and its degradation will elevate. Therefore, manned spaceflight - an expansion of 'the realm of human experience' [Mindell 2008, 
270] - needs to be preserved as an ontological and ecological enterprise. By securing embodied and meaningful engagement with the universe, humans will promote conditions for maintaining the fullness of their own terrestrial existence and a healthy extraterrestrial milieu.

\section{REFERENCES}

Arnould J., 2013. Tele-Reality: How Space Technology Transforms Human Perceptions of Space, Time, and Self. Astropolitics, vol. 11, no. 3, pp. 231-237.

Borgmann A., 2010. Reality and Technology. Cambridge Journal of Economics, no. 34, pp. 27-35.

Borgmann A., 1984. Technology and the Character of Contemporary Life: A Philosophical Inquiry. Chicago; London, The University of Chicago Press.

Brown A., 2006. Assidents, Engeneering, and History of NASA 1967-2003. Dick, S.J., Launius R.D. (eds.). Critical Issues in the History of Spaceflight. Washington, D.C NASA SP-2006-4702.

Clynes M., 1995. Sentic Space Travel. Cyborg Handbook. New York; London, Routledge.

Clynes M., Kline N., 1995. Cyborgs and Space. Cyborg Handbook. New York; London, Routledge.

Gerovitch S., 2006. Human-Machine Issues in the Soviet Space Program. Critical Issues in the History of Spaceflight. Washington, D.C NASA SP-2006-4702.

Gerovitch S., 2011. "Why are We Telling Lies?”: The Creation of Soviet Space History Myths. The Russian Review, vol. 70, no. 3, pp. 460-484.

Gerovitch S., 2014. Voices of the Soviet Space Program: Cosmonauts, Soldiers, and Engineers Who Took the USSR into Space. New York, Palgrave Macmillan.

Gerovitch S., 2015. Soviet Space Mythologies: Public Images, Private Memories, and the Making of a Cultural Identity. Pittsburgh, University of Pittsburgh Press.

Hersch M., 2009. Checklist: The Secret Life of Apollo's 'Fourth Crewmember. The Sociological Review, vol. 57, no. 1, pp. 6-24.

Klein J., 2012. The Influence of Technology on Space Strategy. Astropolitics, vol. 10, no. 1, pp. 8-26.
Krige S., 2006. Technology, Foreign Policy, and International Cooperation in Space. Critical Issues in the History of Spaceflight. Washington, D.C NASA SP-2006-4702.

Launius R., 2006. Compelling Rationales for Spaceflight? History and the Search for Relevance. Critical Issues in the History of Spaceflight. Washington, D.CNASA SP-2006-4702.

Lebedev V., 1988. Diary of a Cosmonaut: 21 Days in Space. New York; Toronto; London; Sydney; Auckland, Batman Books.

McCurdy H., 2006. Observations on the Robotic Versus Human Issue in Spaceflight. Critical Issues in the History of Spaceflight. Washington, D.C NASA SP-2006-4702.

Mindell D., 2006. Human and Machine in the History of Spaceflight. Critical Issues in the History of Spaceflight. Washington, D.C NASASP-2006-4702.

Mindell D., 2008. Digital Apollo: Human and Machine in Spaceflight. Cambridge; Massachusetts; London; England, The MIT Press.

Roscosmos TV Space Dimension of Valentin Lebedev: An Interview. Video Series Scientists About Space, 2017. URL: https://www.youtube.com/ watch? $\mathrm{v}=\mathrm{ZKCiGcBbb5s}$.

Savinyh V.P., 1999. Notes from the Dead Station. Moscow, Dom Sistemy Alisa Press.

Sadeh E., 2005. Viewpoint: The Evolution of Access to Space as an Idea and Technology. Astropolitics, vol. 3, no. 3, pp. 305-318.

Sariak G., 2017. Between a Rocket and a Hard Place: Military Space Technology and Stability in International Relations, Astropolitics, vol. 15, no. 1, pp. 51-64.

Siddiqi A., 2010. The Red Rockets' Glare: Spaceflight and the Soviet Imagination, 1857-1957. Cambridge; New York; Melbourne; Madrid; Cape Town; Singapore; Sao Paulo; Delhi; Dubai; Tokyo, Cambridge University Press.

Shayler D.J., 2017. Linking the Space Shuttle and Space Stations: Early Docking Technologies. [S. 1.], Springer Paxis Books.

Usachjov Ju., 2004. Notes of a Cosmonaut. Three Lives in Space. Moscow, Gelios.

Vaughan D., 2006. Changing NASA: The Challenges of Organizational System Failures. Critical Issues in the History of Spaceflight. Washington, D.C NASA SP-2006-4702.

\section{Information About the Author}

Lika Rodin, PhD, Lecturer, School of Health Sciences, University of Skövde, G-hus, Box 408, 54128 Skövde, Sweden, lika.rodin@his.se, https://orcid.org/0000-0001-7118-5581

\section{Информация об авторе}

Лика Родин, $\mathrm{PhD}$, преподаватель факультета медицинских наук, Университет Сковде, здание G, ящик 408, 54128 г. Сковде, Швеция, lika.rodin@his.se, https://orcid.org/0000-0001-7118-5581 